\title{
Metáfora, metonímia, sinédoque e ironia: elementos retóricos de racionalidade no discurso jurídico
}

\author{
Égina Glauce Santos Pereira*
}

\begin{abstract}
Resumo
A metáfora, a metonímia, a sinédoque e a ironia são conhecidas como figuras de estilo ou tropos, que seriam um desvio de sentido, um rodeio inabitual relativamente ao sentido literal (MEYER, 2014). Desde a Antiguidade, essas figuras se estabelecem como primordiais ao discurso com o objetivo de alcançar o auditório. Nesse sentido, serão analisadas as quatro figuras citadas com o objetivo de demonstrar a racionalidade delas, pois podem ser consideradas como tropos-mestres, ainda que alguns teóricos privilegiem a metáfora ou a metonímia. No discurso jurídico tais elementos fazem parte constante da estratégia de seus operadores, assim será utilizada, exemplificativamente, uma decisão judicial. Essa decisão regulamenta a situação em que um professor suprimiu o celular da posse de um aluno, menor de idade, em decorrência do uso desse aparelho em sala de aula. Verificaremos que o uso das figuras coloca uma questão que impõe ao auditório estabelecer uma resposta. Isso gera uma absorção da interrogatividade, que deveria existir em qualquer argumento ou argumentação.
\end{abstract}

Palavras-chave: Figuras. Techné. Retórica. Decisão judicial. Argumentação.

\section{Introdução}

Sabemos que, cotidianamente, as figuras são consideradas nada mais que elementos embelezadores do texto oral ou escrito, muitas vezes desnecessárias no processo comunicativo, mas utilizadas segundo a intenção do orador e o seu público-alvo. Essa concepção ainda é oriunda do tipo de raciocínio que dominou as estruturas científicas e sociais a partir do paradigma do raciocínio lógico e, consequentemente, reduziu a atuação da retórica. Apesar de ter perdido prestígio, a retórica continuou existindo nas sociedades, entretanto, das cinco divisões da techné, determinadas por Quintiliano, citado por Barthes (1975), podemos dizer

* Universidade Federal de Minas Gerais (UFMG). 
que apenas a elocutio (lexis), cuja finalidade é acrescentar o ornamento das palavras (ornare verbis), continuou sendo aplicada constantemente, deixando as outras: a inventio (euresis) - encontrar o que dizer (invenire quid dicas); dispositio (taxis) ordenar o que se encontrou (inventa disponere); actio (hypocrisis) - representar o discurso como um ator: gestos e diç̧ão (agere et pronuntiare); e memória (mném) - recorrer à memória (memoriae andare), sem qualquer ressalto.

Devemos salientar que a divisão apresentada, também entendida como atos, foi criada e continua sendo utilizada, para fins didáticos, pois sabemos que os atos se entrecruzam na produção da teia argumentativa, mesmo com a atenção focada na questão das figuras, antes da retomada dos estudos retóricos na modernidade. Barthes (1975, p. 49) deixa bem claro o todo na construção discursiva, quando afirma que "há que se insistir na natureza ativa, transitiva, programática, operatória dessas divisões, pois se trata de atos de uma estruturação retórica progressiva, indicadas linguisticamente por formas verbais, o que também reforça a referência à ação/atos". Barthes (1975, 2001, 2002), inclusive, faz analogia da "máquina retórica" com a "máquina de fazer meias de Diderot". Nesta última, insere-se, inicialmente, a matéria têxtil e o que se encontra no final do processo são as meias. Sobre esse processo, Diderot (apud BARTHES, 1975, p. 49) diz que "pode-se olhála como um só e único raciocínio de que a fabricação do produto é a conclusão".

A elocutio é o lugar discursivo das metáforas, das metonímias, das sinédoques e das ironias que são conhecidas como figuras de estilo ou tropos, desvios de sentido, ou um rodeio inabitual relativamente ao sentido literal (MEYER, 2014). As figuras retóricas, os ornamentos, tiveram várias definições, que se mesclam entre estilo de linguagem, representação do pensamento, parte do processo de construção do discurso ou mesmo como expressão da racionalidade, pelas escolhas realizadas para alcançar o auditório.

Na sentença judicial analisada, uma modalidade do discurso jurídico, veremos as figuras como uma das partes da construção desse discurso, além de a analisarmos como parte do lógos, inserida na dimensão demonstrativa, pois "direciona-se para um uso da linguagem sob as bases de uma racionalidade mais calculada, embora essa racionalidade se faça presente também nas outras dimensões" (LIMA, 2006, p. 118). Poderemos perceber ainda que o éthos e o páthos também colaboram para a construção do imaginário social, bem como da identidade e da diferença, completando-os uns aos outros. 
A sentença judicial analisada regulamentou uma situação levada a judice a respeito de um aluno, menor de idade, ${ }^{1}$ representado por sua mãe, que exigia reparação por dano moral de seu professor, em decorrência de este ter recolhido o aparelho celular daquele, sob o argumento de que o aluno estava utilizado o celular em sala de aula. Foi proferida no Tribunal de Justiça do Estado de Sergipe, na $1^{\text {a }}$ Vara Cível e Criminal de Tobias Barreto, no Juizado Especial - Cível, em 29 de maio de 2014, e foi divulgada na íntegra. ${ }^{2}$ Tornou-se paradigma pelo seu conteúdo em decorrência do eco social sobre os papéis sociais do professor, do aluno, dos pais e dos próprios anseios da sociedade na modernidade, fato muito discutido na mídia atualmente, inclusive sobre violência escolar e valores éticos e morais. No estado de Minas Gerais, algumas ações administrativas têm sido tomadas no sentido de se evitar o uso de aparelho celular na escola, como aplicação de sanções administrativas $^{3}$ e aplicação de multa aos pais. ${ }^{4}$

Meyer (2014) e Vico (apud BARTHES, 1975, p. 97) consideram as figuras escolhidas como tropos-mestres. Para Vico, a Poesia era a linguagem original, "as quatro grandes figuras arquetípicas foram inventadas na ordem, não por escritores, mas pela humanidade em sua idade poética: Metáfora, depois a Metonímia, depois Sinédoque, depois Ironia; na origem elas eram empregadas naturalmente". E ainda afirma Vico que a condição de "figura" surgiu apenas quando passou a existir uma oposição paradigmática dela com outra linguagem. Já para Meyer (2007, 2014), são conhecidas como figuras de estilo ou tropos, um rodeio inabitual relativo ao sentido literal, que proporciona um desvio de sentido.

Os quatro tropos-mestres estão no mesmo patamar, não há privilégio de uma figura em detrimento de outra, e possibilitam a construção de uma relação lógica quanto à propriedade, atuando sobre a diferença e a identidade. Nesse sentido, teríamos a metáfora, a metonímia e a sinédoque (MEYER, 2014), mas a ironia teria outra forma de diálogo, pois sua essência demandaria também conhecer o contexto, a situação comunicativa, uma avaliação do sujeito acerca do que é dito.

1 Para o direito, menor de idade é aquele que não pode se representar judicialmente, necessitando de representantes para expressar sua vontade.

2 Para saber mais, consulte: <http:/oglobo.globo.com/sociedade/tecnologia/aluno-processaprofessor-por-celular-retirado-em-sala-de-aula-perde-12718573 $>$; $\quad<$ http://www.migalhas.com.br/ Quentes/17,MI202067, 91041Juiz+nega+dano+moral+a+aluno+que+teve+celular+tomado+em+sala + de+aula $>;<>;<>$.

3 Para saber mais: <http://www.otempo.com.br/cidades/celular-usado-em-sala-de-aula-\%C3\%A9recolhido-e-levado-para-o-f\%C3\%B3rum-1.889749>.

4 Para saber mais: <http://www.estadao.com.br/noticias/geral,juiz-multa-pais-de-aluna-por-usarcelular-em-escola>. 
Burke (apud MEYER, 2007, p. 81) disse que: “esses quatro tropos são pontos de vista sobre o mundo: a metáfora dá uma perspectiva, a metonímia oferece uma redução, a sinédoque serve para representar e, finalmente, a ironia se pretende dialética".

Sabemos que a questão da identidade e da diferença na modernidade insere a perspectiva racional de determinar o uso de uma ou outra para adequar a intenção de comunicação do orador em relação ao seu auditório. Assim, compreendemos que "a retórica - por lidar com a identidade e a diferença - precisa das figuras para acentuar e criar uma, deixando a outra de lado e eliminando-a" (MEYER, 2007, p. 82).

Dessa forma, utilizaremos o jogo da identidade e da diferença, proposto por Meyer $(2007,2014)$, em que é possível traçar uma linha imaginária, que vai da sinédoque à metáfora e vice-versa, sendo certo que a ironia também fará parte dessa linha, mas representando-se como ruptura com a identidade. "As relações entre x e y, A e B permitem definir as quatro figuras principais da retórica clássica, que são a metáfora, a metonímia, a sinédoque e a ironia." (MEYER, 2007, p. 81.)

As semelhanças permitem que analisemos as figuras de retórica no seguinte sentido: "Não é porque dizer A é dizer B que A é B. Mas, quando podemos fazer tal afirmação, estamos lidando com o que chamamos de figuras de retórica" (MEYER, 2007, p. 79). Assim, “dizer se $<<x$ é A $>>$ é dizer que $<<$ y é B $>>$; mas em vez de o verificar, de o testar ou simplesmente de preservar a diferença, o tropo afirma que $<<\mathrm{x}$ é A, y é B $>>$ amalgamando os $\mathrm{x}$ e os y e apagando a diferença AB para os assimilar" (MEYER, 2014, p. 69).

Nesse contexto, as figuras representam algo, e, assim, fazem parte da racionalidade do discurso, pois a escolha para realizar a afirmação se deu através de determinados elementos e não de outros. Enfim, para a representatividade acima, o importante é o auditório interpretar o tropo, como proposto ou não, ${ }^{5} \mathrm{e}$ expor a figura enquanto tal, demonstrando que o auditório conhece os "lugarescomuns" partilhados pelas figuras e acionando a relação entre autor/locutor.

Compreendemos que a figura de estilo lembra aquilo que é comum aos interlocutores, podendo ou não ser aceita pelo auditório, mas sendo possível o reconhecimento do dito, ou seja, mesmo respondendo à questão proposta decifrando-a, seja pela forma, seja pelo contexto.

5 O fato de interpretá-lo (reconhecê-lo) não quer dizer que haverá aceitabilidade, ou seja, adesão, pois poderá propiciar tanto o distanciamento (negação) quanto a proximidade (adesão). 
Concordamos com Aristóteles (1982) quando afirma que o afastamento do sentido corrente faz um discurso parecer mais solene, como percebemos, por exemplo, no uso do termo "alumno". Ao produzir uma linguagem não familiar, pois busca com o uso do termo a admiração das pessoas, que somente admiram o que está distante/afastado, e aquilo que provoca admiração torna-se coisa agradável.

Compreendemos a noção de racionalidade pensando na razão construída no âmbito do verossímil, do plausível, do provável, na medida em que escapa às certezas do cálculo, mas permitindo uma construção lógica argumentativa, permitindo uma revisão das decisões e a possibilidade de adesões ou não. MacCormick (2006) completa a ideia, pois admite que há premissas normativas fundamentais que não são produto da cadeia de raciocínio lógico, mas de questões afetivas, na maioria das vezes moldadas pelo aspecto social, que justificam a existência de divergências morais fundamentais. Tal fato é primordial para analisarmos as figuras utilizadas na sentença judicial em questão.

\section{Elocution e discurso decisório}

As figuras são, normalmente, vistas como elemento subjetivo, já que a sua escolha permite uma margem maior de significação. A permissão de significação, por ser lógica, dentro de certos preceitos possíveis, os quais podem ser retirados do próprio contexto e de valores textuais inseridos, não reduziria a objetividade do texto. Assim, pode não ser extremamente usual a sua utilização em textos decisórios jurídicos, mas nada obsta que ocorra, desde que se mantenha a função da decisão: criar, modificar, extinguir direitos ou situações jurídicas, bem como criar uma nova realidade de forma justificada. Como requisito para validade no mundo jurídico, o julgador deverá fundamentar sua decisão, motivando-a, justificando e apontando argumentos para as razões de decidir. Deverá ainda atender aos critérios constitucionais previstos no artigo 93, IX, da CRFB, ${ }^{6}$ e, no qual está prevista, inclusive, sanção decorrente de sua inobservância.

6 Art. 93 - Lei complementar, de iniciativa do Supremo Tribunal Federal, disporá sobre o Estatuto da Magistratura, observados os seguintes princípios:

$[\ldots]$

IX - todos os julgamentos dos órgãos do Poder Judiciário serão públicos, e fundamentadas todas as decisões, sob pena de nulidade, podendo a lei limitar a presença, em determinados atos, às próprias partes e a seus advogados, ou somente a estes, em casos nos quais a preservação do direito à intimidade do interessado no sigilo não prejudique o interesse público à informação; (Grifo nosso.) 
Além disso, deverá a sentença, como um dos discursos decisórios ${ }^{7}$ produzidos, sob o ponto de vista formal, ser dividida em três partes: o relatório, o fundamento e o dispositivo. O relatório é a narrativa dos passos processuais, que são reconstruídos pelo juiz, apresentando a tese e a antítese formulada no processo, além dos principais atos procedimentais realizados. Essa primeira parte, em procedimentos analisados perante o Juizado Especial, em função da permissão da Lei 9.099, de 26 de setembro de 1995, que dispõe sobre os Juizados Especiais Cíveis e Criminais, não é necessária, sendo permitida sua dispensa. Isso porque as causas julgadas nessa instância são consideradas de pouca complexidade com referência aos assuntos tratados, não sendo necessária realização de determinadas provas consideradas complexas, como as periciais, por exemplo. Os procedimentos do Juizado Especial são considerados mais simplificados tanto procedimentalmente como para as decisões. É na última parte, conhecida como dispositivo, que se define o destino das partes. Nela se determina a improcedência ou procedência do pedido, bem como as cominações (determinações) legais. A decisão analisada foi proferida no Juizado Especial Cível e deve observar as regras dessa instância de produção.

A decisão judicial é um discurso fundamentado em autoridade, pois cumpre um dever de Estado e, ao mesmo tempo, exercita uma parte flexível das obrigações estatais e limites sob o influxo de procedimentos, que pendulam entre o conteúdo da decisão e sua exteriorização formal: a sentença. Nessa construção procedimental, parte-se para a questão do juízo de valor que o destinatário do discurso jurídico deverá aplicar, mas que também deverá justificar a aplicação de uma das teses na sua decisão, considerando "norma e avaliações como juízo de valor [...] Ações podem ser louváveis ou censuráveis, mas não razoáveis ou desarrazoadas" (PERELMAN, 1999, p. 167). Para Perelman (2004, p. 209), “o raciocínio jurídico manifesta-se, por excelência, no processo judiciário. De fato, o papel específico dos juízes é dizer o direito - e não o criar - embora freqüentemente a obrigação de julgar, imposta ao juiz, leve-o a completar a lei, a reinterpretá-la e a torná-la mais flexível".

A interpretação e a complementação da norma para moldá-la ao sistema jurídico requer uma construção do fato social sob o olhar jurídico. É nesse ponto

7 Há possibilidade de se produzirem várias modalidades de decisões, sendo a sentença uma delas. Além do mais, Bittar (2001) divide o discurso jurídico segundo as peculiaridades discursivas em: normativo, com característica de poder-fazer-dever; burocrático, poder-fazer-fazer; decisório, poder-fazer-dever e científico, poder-fazer-saber. Tal classificação permite verificar que é o poder-fazer-dever, que faz a sentença judicial performativa, característica que lhe é inerente. 
que o julgador poderia apropriar-se das figuras para argumentar em sua decisão.

Barthes (1975, p. 42) diz que as "figuras" eram representadas nos tratados de Retórica pela denominação de retórica paradigmática, mas que não poderiam ser separadas da "construção oratória", chamada de retórica sintagmática, pois seriam necessárias e complementares. Insta esclarecer que a Elocution não deve ser vista apenas como figuras, apesar de estas se encontrarem inseridas nela, para Barthes (1975, p. 89) "a melhor tradução de Elocutio talvez não seja elocução (demasiado restrita), mas enunciação, ou, mais estritamente, locução (atividade locutória)".

Nesse sentido, a elocução não diz respeito apenas à palavra oral, mas também à redação escrita do discurso, ao estilo. É a etapa linguística, quando se elabora a construção do discurso, a argumentação através de palavras, frases e orações. Em sentido técnico, é a redação do discurso para Reboul (2004, p. 61 e 247). O que permite as escolhas lexicais, gramaticais e semânticas para sua construção.

Assim, após o orador encontrar o que dizer, "a inventio remete menos a uma invenção (dos argumentos) do que a uma descoberta: tudo já existe, basta reencontrá-lo: é uma noção mais "extrativa" do que "criativa". Isso é corroborado pela designação de um "lugar" (a Tópica), de onde se pode extrair os argumentos e aonde se deve levá-los" (BARTHES, 1975, p. 51, grifo nosso). Os tropos ou "lugares comuns" eram uma lista em que se buscavam os elementos para a construção do discurso. O termo invenção atualmente é diferente semanticamente do uso daquela época. Em seguida, seria necessário expor a investigação proporcionada pela invenção, que se daria pela disposition ou taxis, “[...] o arranjo e a hierarquização desse material [repertório temático em que se há de buscar as provas e o material, necessário à consecução dos propósitos do produtor - inventio]" (MEYER, 2007, p. 11).

Só então, quando encontrados e repartidos os argumentos maciçamente nas partes do discurso, eles precisam "ser traduzidos em palavras", sendo essa a função da elocutio, à qual costumamos reduzir a retórica, em razão do interesse dos modernos pelas figuras de retórica, parte (e frise-se bem, apenas parte) da elocutio (BARTHES, 1975, p. 212).

Como podemos observar, desde a Antiguidade, as figuras se estabelecem como primordiais ao discurso com o objetivo de alcançar o auditório. Perelman e Olbrechts-Tyteca (2000) compreendiam que o objetivo das figuras, em geral, era trazer para o discurso um elemento que seria atenuado ou reforçado, fazendo-o mais essencial do que em situações nas quais não se utilizasse tal estratégia, e 
destacam o papel da função argumentativa existente nas figuras, sendo importante "[...] mostrar em que e como o emprego de algumas figuras determinadas se explica pelas necessidades da argumentação" (PERELMAN; OLBRECHTS-TYTECA, 2000, p. 190). Nesse sentido, a decisão judicial se apropriaria das figuras com o fim de argumentar, construir o posicionamento para definir a questão, ou questões, proposta pelas partes.

Só há figura quando podemos operar uma dissociação entre o uso normal de uma estrutura e seu uso no discurso, quando o interlocutor faz uma distinção entre a forma e o fundo, que lhe parece impor-se. Mas é quando essa distinção, percebida logo no início, se extingue em virtude do efeito mesmo do discurso, que as figuras assumem todo o seu significado argumentativo, segundo Perelman e Olbrechts-Tyteca (2000).

Fica evidente a necessidade de se contextualizar para uma possível análise, mas a conclusão geral é a possibilidade de utilizar as figuras como elementos argumentativos, e, com isso, não há diferença entre o que Perelman e OlbrechtsTyteca (2000) apresentam, entre o que Meyer $(2007,2014)$ diz quanto a diferença e semelhança, ou ainda entre a retomada aristotélica proposta por Barthes (1975) ou Reboul (2004).

Nenhum deles apresenta as figuras apenas como possibilidade ornamentatória, exatamente porque a palavra ornamento no grego não se apresentava apenas como embelezamento, fato confirmado na modernidade, e, sim, como parte essencial à armadura do soldado, por exemplo. Caso consideremos ornamento como essencial, seria desnecessário todo o processo determinante até aqui para demonstrar a necessidade das figuras como elemento argumentativo, que permite a dissociação ou associação pela construção do discurso. Nesse sentido, verificamos que as figuras utilizadas na sentença judicial possuem caráter argumentativo, com a finalidade de buscar a adesão não apenas das partes processuais, mas também de toda a sociedade pelo seu caráter geral.

\section{Estrutura da figuratividade: elemento de racionalidade}

É difícil criar uma estrutura que se permita dizer se é ou não figura, mas Meyer $(2014)^{8}$ define uma estrutura geral do tropo propondo três características

8 Para Meyer (2014), os tropos são figuras de estilo, mas também do humano: o discurso figural diz mais que qualquer outro discurso, pois, ao optarem por uma expressão tropológica, os homens 
essenciais, chamando-as de estrutura da figuratividade.

A primeira delas nos diz que o tropo coloca uma questão que, mesmo assumindo um status de resposta, é uma resposta problematológica, ou seja, uma resposta que interroga o outro e faz com que sejam estabelecidos laços para se chegar a uma conclusão, funcionaria como um argumento lançado que exige do outro alguma ação. O uso da figura deixa a cargo do interlocutor a responsabilidade de interpretar o que lhe foi dito. Em segundo lugar, o tropo cria uma identidade: "dizer A é dizer B”, em que A é B, de forma figurada, e não literal, e é essa identidade que revela a problematicidade lançada ao auditório, o problema de se saber o que está em questão no que não é dito de maneira literal. Por último, o tropo é poético, produzindo efeitos de sentido, colocando "a linguagem no domínio inovador do pensamento" (MEYER, 2014, p. 113).

Para Meyer (2007, p. 82) "a figuratividade abole a antítese e, em consequência, a questão parece resolvida". No primeiro momento, "a figura coloca uma questão. [...] Se existe figura, existe questão, resposta problematológica, uma resposta que interroga o auditório e o força a responder para esclarecer a questão".

Exemplificativamente, na epígrafe, podemos representar a estrutura da figuratividade, apresentada por Meyer (2014).

Aos professores, fica o convite para que não descuidem de sua missão de educar, nem desanimem diante dos desafios, nem deixem de educar as pessoas para serem "águias" e não apenas "galinhas". Pois, se a educação sozinha não transforma a sociedade, sem ela, tampouco, a sociedade muda. (Paulo Freire) (SERGIPE, 2014).

Literalmente, não é verdade que o professor deva educar as pessoas para “serem 'águias' e não apenas 'galinhas' ”, ele deve educar no sentido de transmitir determinados conhecimentos e padrões de comportamento, a fim de garantir a continuidade da cultura de uma sociedade. No sentido mais amplo ainda, a educação deveria possibilitar a socialização, além de transmitir os hábitos que capacitam o indivíduo a viver numa sociedade, hábitos esses que começam na primeira infância, implicando o ajustamento a determinados padrões culturais, nos quais estão inseridos questões comportamentais e conhecimentos considerados necessários. Então, o que se projeta desse processo deve ser internalizado pelo aluno, que se identifica com o comportamento de águia ou de galinha, segundo o em seu sentimento mais profundo, através da maneira com que tratam uma questão. 
reino animal, e que pode ou não fazer diferença no comportamento do indivíduo na sociedade, com suas possíveis ações.

Nesse ínterim, encontramos o segundo elemento de figuratividade: a águia, a galinha e o educando preenchem os critérios, já que a diferença existente deve desaparecer, estabelecendo-se "uma identidade, que sabemos é uma ficção". Assim, "A diferença eclode como questão, o que impele o auditório a procurar a solução como um outro sentido que dá conta da identidade figural entre A e B [entre os elementos utilizados figurativamente]."

Enquanto o auditório determina se educando, se águia ou se galinha, encontramos o último elemento da figuratividade: Segundo Meyer, (2014, p. 113), "o tropo exprime pois o movimento do pensamento na sua própria interrogatividade, deixando a cada um o cuidado de concluir, de fazer desaparecer a questão levantada". Assim, "o tropo coloca a linguagem no domínio do pensamento, onde ela oscila de predicados para sujeitos e que para julgar se interroga ainda antes de julgar, quer dizer, antes de responder" (MEYER, 2014, p. 113, grifo nosso).

A conclusão do auditório é que permitirá compreender se ocorreu ou não o reconhecimento, além da adesão ao que estava sendo proposto ou não.

\section{Metáfora, metonímia, sinédoque e ironia}

Cada escolha feita na produção textual permite perceber as estratégias utilizadas para alcançar o público-alvo, causar-lhe empatia com a decisão, e, ao mesmo tempo, justificar o porquê daquela escolha e não outra. Apesar de podermos dizer que a decisão é transgressiva, tanto na forma como no conteúdo, compreendemos que a legalidade não fica comprometida pelo fato de o enquadramento das razões de direito também ocorrer.

A própria inserção de epígrafe no discurso jurídico decisório já é uma transgressão, o que não ocorreria se estivéssemos lidando com o discurso jurídico científico. A epígrafe é um pré-texto, que serve de bandeira ao texto principal, por compactar o pensamento do autor. Nesse sentido, a escolha da epígrafe e a sua colação na sentença diz muito, permitindo uma leitura da imagem de si (éthos), pelos valores professados na epígrafe, mas, além disso, permite a construção da imagem do outro (páthos). A própria citação de Paulo Freire permite a construção de uma linha lógica a se desenvolver na decisão pelos argumentos fundamentadores, a fim de servir de subsídio para a legalidade e a legitimação da decisão. 
Outra transgressão que pode ser apontada é referente ao assunto, pois há inserção de argumentos de outra ordem: educacional, pedagógica, além de argumento do mundo jurídico. Os primeiros já podem ser apontados de início pelo texto da epígrafe, e o argumento de autoridade é evidente, pois o trecho é de autoria de Paulo Freire, conhecido como educador, pedagogo e filósofo, nome de peso nacional, também reconhecido em todo o mundo pelo movimento da pedagogia crítica. Porém, o mais importante para a presente análise é a metáfora apresentada nela:

Aos professores, fica o convite para que não descuidem de sua missão de educar, nem desanimem diante dos desafios, nem deixem de educar as pessoas para serem "águias" e não apenas "galinhas". Pois, se a educação sozinha não transforma a sociedade, sem ela, tampouco, a sociedade muda. (SERGIPE, 2014, grifo nosso.)

A imagem do professor é construída em toda a extensão da decisão, e isso é feito pela representação do papel construído para ele na sociedade em relação à sua atribuição, frisada pela palavra "educar" no lugar de "ensinar". Mas “educar as pessoas para serem águias e não apenas galinhas" é o cerne da metáfora enquanto elemento discursivo.

O uso das palavras 'águia' e 'galinha' não é aleatório e remete a significados, a 'lugares-comuns'. Têm-se duas aves, distintas em suas categorias, uma voltada para ganhar o céu (ave de rapina), livre, que não se submete a regras impostas pelo ser humano, e outra que cumpre seu papel no chão (ave doméstica), dependente do ser humano, inclusive para sua alimentação, podendo ser explorada na produção, limitada ao seu lugar de atuação. As propriedades da galinha e da águia se alinham na construção dos valores necessários ao ser humano, que adquiriria esses valores.

A metáfora, para Meyer (2007, p. 82), é considerada

[...] a figura por excelência da identidade frágil, e é por esse motivo que desde Aristóteles ela ocupa um lugar central, quase genérico, em relação a todas as outras figuras, como se dela decorressem. [...] Mas a metáfora não o diz, ela convida a concluí-lo, como o entimema.

Isso ocorre porque a passagem entre a propriedade é implicada e não dita realmente, proporcionando a eliminação das diferenças, e a propriedade 
subentendida torna-se a base da identificação. A metáfora joga com a identidade entre conjuntos, por isso, quando se diz: "nem deixem de educar as pessoas para serem 'águias' e não apenas 'galinhas'”, percebemos que nessas orações se operam identidades entre domínios disjuntos, revelando a semelhança entre elas, buscando se apagar as diferenças. Ou seja, pessoas fazem parte da humanidade, as quais podem possuir um elo identitário com "galinhas" (ave rasteira conhecimento comum, vulgar) ou com "águias" (ave de rapina - conhecimento especial, diferenciado), que é colocado em evidência. Assim, temos que: ou as pessoas são galinhas ou são águias, em sentido figurado, obrigando o interlocutor a procurar este elo conjuntivo que reúne homens, águias e galinhas, buscando-se, então, a identificação.

Porém, ao mesmo tempo, há uma aproximação de dois termos entre os quais há alguma relação de semelhança (os dois pertencem à espécie aves), chamamos de símile, também conhecida como comparação. Fica mais evidente a metáfora, pois ressalta a ideia de mudar e ser uma coisa e não outra em essência, principalmente quanto às características que as posicionam nesse sentido. Isso acontece, pois o gênero "animais", além de insere a espécie "humana", também insere "aves", e enquanto "aves": "galinha" ou "águia". Meyer (2014) diz quanto à metáfora que ela, na verdade, permite uma propriedade diferente da usual. Assim, seja como águia, seja como galinha, as propriedades das aves são transportadas aos humanos (alunos) através de humanos (professores).

Podemos ainda perceber a metonímia da obra pelo autor em relação ao trecho: "A águia e a galinha”, de autoria de Leonardo Boff, isso porque: “[...] ela privilegia um nome de indivíduo ou coisa para especificar algo relativo a outro indivíduo ou outra coisa" (MEYER, 2007, p. 83). Então, a metonímia instaura uma identidade entre dois conjuntos, por uma relação que pode ser de causa e efeito, o feito pela causa, ou, como no caso, entre a obra e o autor (A águia e a galinha - Leonardo Boff), mas a estrutura é a mesma "uma determinação que se transforma em um nome e o substitui, de onde o efeito de identidade da figura" (MEYER, 2007, p. 85); "[...] ela privilegia um nome de indivíduo ou coisa para especificar algo relativo a outro indivíduo ou outra coisa" (MEYER, 2007, p. 83).

Conceitualmente, metonímia e sinédoque se diferenciam (embora por vezes seja difícil estabelecer a diferença) pelo fato de a última consistir em instaurar uma identidade entre dois conjuntos que estão imbricados, estabelecendo uma relação entre uma parte, tida como essencial, e um todo (físico ou metafísico), no qual 
está contida.

Para sinédoque, temos "reverencio o verdadeiro herói nacional [...]: o professor" (SERGIPE, 2014). Percebemos a designação do objeto pelo nome de outro objeto, com o qual ele forma um conjunto, um todo, encontrando-se a ideia de um compreendido na existência do outro (herói - professor). Ela assimila o todo à parte, ou o inverso, e a consideramos com "uma identidade que assenta no facto de tomarmos a parte pelo todo" (MEYER, 2007, p. 83). Aqui, os conjuntos não são distintos, como na metáfora, nem tangentes, como na metonímia, mas são imbricados, e a diferença diminui claramente. Outro exemplo: "O país como todo, é verdade. Os alunos e pais de alunos, diretamente” (SERGIPE, 2014, grifo nosso).

A ironia "manifesta-se por uma disjunção; contudo, já não se trata de juntar dois conjuntos de objetos ou de propriedade por uma relação de continuidade, mas decididamente de opor esses dois conjuntos" (MEYER, 2014, p. 119). Visualizamos claramente essa oposição no seguinte trecho: “[...] mas houve uma época em que ser pego em sala de aula fazendo palavras-cruzadas ou trocando bilhetes com outros discentes era motivo para, no mínimo, fazer corar a face do aluno surpreendido" (SERGIPE, 2014). O sentido da ironia está na perspectiva de a representante legal do aluno entrar com uma ação judicial para requerer uma indenização por dano moral ao professor que age dentro do seu papel disciplinador. Aqui a identidade é mínima, e a diferença, máxima (MEYER, 2014).

Toda a decisão judicial poderia ser analisada sob a perspectiva dos troposmestres, sob a estrutura de figuratividade (MEYER, 2007, 2014). A linha imaginária que revela o jogo da identidade e da diferença, em cada uma dessas figuras, pode ser abordada sob o ângulo da identidade: a metáfora institui uma identidade entre dois conjuntos disjuntos; a metonímia estabelece uma identidade entre dois conjuntos próximos ligados por uma relação; e, finalmente, a sinédoque constrói uma identidade entre dois conjuntos inclusos, revelando uma diferença mínima; e, por fim, a ironia, que rompe definitivamente com qualquer identidade (MEYER, 2014). Ao olhar pela perspectiva da diferença, basta inverter o eixo de análise. 


\section{5 À guisa de uma conclusão}

O magistrado constrói uma imagem do coletivo pela utilização de "Juízos de valor e, mesmo, sentimentos puramente subjetivos podem, mediante artifícios de apresentações, ser transformados em juízo de fato" (PERELMAN; OLBRECHTSTYTECA, 2000, p. 190).

Toda a decisão judicial serve para construir a imagem de si e a imagem do outro, com o fito de repensar o papel do professor, antes e depois: “[...] O professor era autoridade de fato e de direito na sala de aula. [...] Ensinar era um sacerdócio e uma recompensa. Hoje, parece um carma." (SERGIPE, 2014, grifo nosso). Figuras metafóricas para ressaltar a construção do pensamento. Assim, mesmo que o professor não seja autoridade de fato e de direito, o que se discute na decisão são os valores éticos e morais de respeito e de civilidade, que se perderam com a questão de não haver mais autoridade em sala de aula.

Os modos de dizer do magistrado não apenas formulam o papel do professor, mas também permitem um autorretrato discursivo, espelhado nas escolhas discursivas, assim, como diz Amossy (2005, p. 10) "a construção de uma imagem de si destinada a garantir o sucesso do empreendimento oratório".

Observamos que a sentença judicial analisada, quanto ao uso das figuras, coloca uma questão, que impõe ao auditório estabelecer uma resposta não apenas quanto à justiça, mas também quanto à educação em nosso país e o éthos social de desvalorização do papel do professor na sociedade. Isso gera uma absorção da interrogatividade, que deveria existir em qualquer argumento ou argumentação.

As figuras dispensam a solução, pois se apresentam como respostas, são estilos figurativos, que permitem "um momento de conciliação do contraditório, que é abolido ao dizermos 'É só um jeito de falar'” (MEYER, 2007, p. 80), mas que em uma sentença judicial é muito mais que um modo de falar, é uma forma de buscar uma lógica argumentativa e também uma legitimação do discurso jurídico por argumentos extrajudiciais, ainda que faça uso da racionalidade jurídica, quanto a fatos e normas, exigência do discurso produzido em uma instância regulamentada.

No mais das vezes, o esforço do juiz se faz para

[...] atribuir aos elementos nos quais se apóia o estatuto mais elevado possível, o estatuto que usufruiu o acordo mais amplo. Assim é que o estatuto de valor será atribuído aos sentimentos pessoais, o estatuto 
de fato será atribuído aos valores. Os sentimentos e impressões pessoais são em geral expressos como juízos de valor largamente compartilhados (PERELMAN; OLBRECHTS-TYTECA, 2000, p. 203).

É exatamente o lugar das figuras argumentativas em questão, os lugares-comuns da presente decisão: educação, professor, aluno e os papéis desempenhados por cada um.

\title{
Metaphor, metonymy, synecdoche and irony: rhetorical elements of rationality in legal discours
}

\begin{abstract}
Metaphor, metonymy, synecdoche and irony are known as figures of style or tropes, that would be a deviation of direction, one unusual detour regarding the literal sense (MEYER, 2014). Since antiquity, these figures are established as primordial to the discourse with the goal of reach the audience. Thus, the four figures will be analyzed with the goal of demonstrate the rationality of them, because they can be considered as tropes-masters, as some theorists privilege the metaphor or metonymy. In legal discourse such elements are constant part of the strategy of their operators, so it will be used, exemplarily, a court decision. This decision governs the situation where a teacher took the phone of a student, minor, arising from the use of this device in the classroom. It is to be checked that the use of the figures put a question that requires the audience to establish a response.
\end{abstract}

Keywords: Figures. Techné. Rethoric. Judicial Decision. Argumentation.

\section{Referências}

AMOSSY, Ruth (Org.). Imagens de si no discurso: a construção do ethos. São Paulo: Contexto, 2005.

ARISTÓTELES. A arte retórica e a arte poética. São Paulo: Difusão Européia, 1982.

BITTAR, Eduardo C. B. Linguagem jurídica. 5. ed. São Paulo: Saraiva, 2001. BARTHES, Roland. A Retórica Antiga. In: COHEN, Jean et al. Pesquisas de retórica. Petrópolis, Rio de Janeiro: Vozes, 1975. p. 147-221.

BARTHES, Roland. A aventura semiótica. São Paulo: Martins Fontes, 2001. 
BARTHES, Roland. L'ancienne rhétorique. In: BARTHES, Roland. OEuvres complètes III: livres, textes, entretiens, 1968-1971. Paris: Seuil, 2002. p. 527-601. LIMA, Helcira Maria Rodrigues de. Na tessitura do processo penal: a argumentação no Tribunal do Júri. 2006. 263 f. Tese (Doutorado em Estudos Linguísticos) - Faculdade de Letras, Universidade Federal de Minas Gerais, Belo Horizonte, 2006.

MACCORMICK, Neil. Argumentação Jurídica e Teoria do Direito. São Paulo: Martins Fontes, 2006. Original publicado em 1978.

MEYER, Michel. A retórica. São Paulo: Ática, 2007.

MEYER, Michel. Questões de retórica: linguagem, razão e sedução. Lisboa: Edições 70, 2014.

PERELMAN, Chaïm. Retóricas. São Paulo: Martins Fontes, 1999.

PERELMAN, Chaïm; OLBRECHTS-TYTECA, Lucie. Tratado da argumentação: a nova retórica. São Paulo: Martins Fontes, 2000.

PERELMAN, Chaïm. Lógica jurídica. São Paulo: Martins Fontes, 2004.

REBOUL, Oliver. Introdução à Retórica. São Paulo: Martins Fontes, 2004.

SERGIPE. Tribunal de Justiça. Juizado Especial Cível. Decisão da $1^{a}$ Vara Cível e Criminal de Tobias Barreto. Processo ${ }^{\circ}$ 201385001520, julgado em 29 de maio de 2014.

\section{ANEXO A \\ SENTENÇA JUDICIAL}

Reclamante: T.A.S., representado por sua genitora S.E.R.

Reclamado: O.A.O.N.

Ninguém nega o valor da educação e que um bom professor é imprescindível. Mas, ainda que desejem bons professores para seus filhos, poucos pais desejam que seus filhos sejam professores. Isso nos mostra o reconhecimento que o trabalho de educar é duro, difícil e necessário, mas que permitimos que esses profissionais continuem sendo desvalorizados. Apesar de mal remunerados, com baixo prestígio social e responsabilizados pelo fracasso da educação, grande parte resiste e continua apaixonada pelo seu trabalho. A data é um convite para que todos, pais, alunos, sociedade, repensemos nossos papéis e nossas atitudes, pois com elas 
demonstramos o compromisso com a educação que queremos. Aos professores, fica o convite para que não descuidem de sua missão de educar, nem desanimem diante dos desafios, nem deixem de educar as pessoas para serem "águias" e não apenas "galinhas". Pois, se a educação sozinha não transforma a sociedade, sem ela, tampouco, a sociedade muda. (Paulo Freire)

\section{SENTENÇA \\ I - Relatório}

Dispensado o relatório, na forma do art. 38 da Lei 9.099/95.

\section{II - FUNDAMENTAÇÃO}

O Autor é estudante. O demandado, professor. Neste contexto, já se deveria asseverar que o docente, jamais, traria algum abalo moral àquele ser que lhe foi confiado a aprender. Pelo contrário! O professor é o indivíduo vocacionado a tirar outro indivíduo das trevas da ignorância, da escuridão (alumno: sem luz), para as luzes do conhecimento, dignificando-o como pessoa que pensa e existe (cogito, ergo sum: penso, logo existo, na preciosa lição de Descartes).

O que temos no Brasil? Uma completa inversão deste valor, explicável se levarmos em conta que, no século passado, ficamos aproximadamente 40 anos em duas ditaduras que entenderam o valor da Educação como ferramenta de tirania e alienação, transformando professores em soldados de ideologias totalitaristas, perfilados em salas de aula em que sua disposição espacial dá toda esta diretriz: o professor em pé, discursando; os alumnos sentados, indefesos, recebendo toda carga do "regime".

Vieram os períodos de democracia, e o que se fez? Demonizou-se a educação! Sim, pois eram alinhavadas com os regimes absolutistas, que tinham o "disparate" de ensinar nas aulas de Educação Moral e Cívica, Orientação para a Vida, Organização Social e Política do Brasil e afins que fazer greve era errado; que o indivíduo de bem deve se submeter, sem questionar à autoridade estatal; que quem questiona não é de boa índole...

É certo que o modelo educacional utilizado pelo Estado Novo e pela Ditadura Militar era tendencioso e unifacetado. Não havia espaço para diferenças. Tampouco 
para minorias. Mas o que se fez foi escantear aquele modelo educacional e...

Este é o ponto! O modelo educacional brasileiro de outrora foi abandonado e, até agora, nenhum o sucedeu. É bem verdade que a quantidade de dinheiro aumentou, mas o investimento (não só financeiro) é péssimo. Ainda temos uma maioria esmagadora de centros educacionais no Brasil que remontam ao século XIX, insalubres, massacrantes e nada atrativos, conforme várias matérias jornalísticas despejam periodicamente nos meios de comunicação.

Quem sofre com isso? O país como todo, é verdade. Os alunos e pais de alunos, diretamente. Mas fico a pensar, também, naquele que nasce vocacionado para ensinar, que se prepara anos a fio para isso, e, quando chega o grande momento, depara-se com uma plateia desinteressada, ávida pelos últimos capítulos da novela ou pela fofoca da semana, menos com a regência verbal ou a equação de segundo grau, até porque não possui nenhuma ferramenta "atrativa" para combater a contracultura das massas.

A concorrência é desproporcional, mas houve uma época em que ser pego em sala de aula fazendo palavras-cruzadas ou trocando bilhetes com outros discentes era motivo para, no mínimo, fazer corar a face do aluno surpreendido.

O professor era autoridade de fato e de direito na sala de aula. Era respeitado como tal, pois a sociedade depositava sobre seus ombros a expectativa de um futuro melhor para os mais mancebos. Possuía licença de cátedra, liberdade para escolher o método que houvesse por bem, para melhor alçar o espírito dos pupilos. Ensinar era um sacerdócio e uma recompensa. Hoje, parece um carma.

Voltando à querela: o que pretende o Autor? Reparar seu "sentimento de impotência, revolta, além de um enorme desgaste físico e emocional" (fls. 03, $4^{\circ}$ parágrafo). E por que? Porque o ora Reclamado, na condição de professor, "tomou o celular do aluno, ora REQUERENTE, na sala de aula, isto porque o aluno pegou o celular para ver a hora" (fls. $02,4^{\circ}$ parágrafo, última parte).

Analisando a prova colhida em audiência, vemos que o aluno não comprovou o alegado, não se desincumbindo do ônus probatório previsto no art. 333, I do CPC, ou seja, não comprovou seu fato constitutivo, produzindo tão somente "meras alegações". A prova oral produzida a seu rogo não comprovou em nenhum momento que o aparelho celular foi tomado do autor de forma injusta ou desmotivada. Sucintamente: não há um único elemento probatório em favor da tese empreendida pelo autor.

De outra face, analisando os demais elementos probatórios, vemos que os 
elementos colhidos apontam para o fato de que o Autor não foi "ver a hora". O mesmo admitiu que o celular se encontrava com os fones de ouvido plugados e que, no momento em que o professor tomou o referido aparelho, desconectou os fones e... começou a tocar música.

Aliado a este fato que, repise-se, foi relatado pelo próprio Autor, as testemunhas arroladas pelo Requerido, Professora e Coordenadora do estabelecimento de ensino onde os fatos ocorreram, foram categóricas em afirmar que o mesmo Autor, embora não seja um aluno que "dê trabalho" e não faça as atividades educativas propostas pelos docentes, já foi flagrado em outras vezes com fones de ouvido em plena ministração de aula.

O Requerido, em seu depoimento, afirmou que diversas vezes chamou a atenção do Aluno por utilizar o aparelho celular para jogar ou ouvir música em sala de aula, sendo que em uma certa vez, este chegou a utilizar uma "caixinha de som" durante a aplicação de uma prova.

O que fez o aluno, ora Autor, no dia dos fatos? Além de descumprir a norma encetada no art. 48, VII, de norma emanada pelo Conselho Municipal de Educação, que veda ao aluno utilizar-se de aparelho celular durante o horário de aula, salvo se fizer parte da atividade pedagógica, ainda desobedeceu ao comando do Professor que, por outras vezes, já o advertira sobre o uso do aparelho celular.

Pode-se até entender que o Discente desconheça a legislação municipal sobre os direitos e deveres dos alunos em sala de aula. O que não se pode admitir é que um aluno desobedeça, reiteradamente, a um comando ordinário de um professor, como no presente caso.

Vivemos dias de verdadeira "Crise de Autoridade" na educação brasileira. Crise esta causada pelo sucateamento retromencionado dos estamentos educacionais, onde a figura do Professor é relegada a um papel pouco expressivo na sociedade. Hoje, o professor é tido como uma pessoa que estudou muito e não chegou a lugar nenhum, quando não se diz coisa pior.

E ao exercer este "carma", não tem o respeito dos discentes, que passam a questioná-lo sem nenhum embasamento lógico ou pedagógico, em puro exercício da "arte pela arte, crítica pela crítica", causando profundas sequelas naqueles que deveriam ser os mais interessados em aprender.

Ressalte-se, ainda, que as provas orais pleiteadas pelo Autor em nada acrescentaram para o deslinde dos fatos, limitando-se a se referir ao episódio pela ótica do Autor, pois souberam pelo mesmo dos fatos, nada acrescentando aos 
elementos colhidos.

Assim, diante de todos os elementos probatórios colhidos nos presentes autos, não merece prosperar a pretensão encartada na inicial: a uma, porque o aparelho celular foi tomado pela utilização indevida de seu dono, no caso o Autor; a duas, porque esta má utilização foi praticada em outros momentos, o que é corroborado pelos depoimentos prestados pelas pessoas arroladas pelo Requerido, vale dizer, também docentes da escola; a três, porque se houve alguma demora na restituição do aparelho, a mesma se deveu pela mesma demora dos Responsáveis Legais pelo Autor em se apresentarem para receberem o celular; a quatro, ainda que houvesse algum excesso temporal, este não causou nenhum abalo moral ao Autor, pois o mesmo não utiliza seu aparelho para trabalhar, estudar ou qualquer outra atividade, exceto para mero deleite e lazer, o que não caracteriza, a meu sentir, nem dano moral nem suposto abuso de direito por parte do Reclamado; e a cinco, porque julgar procedente esta demanda é desferir uma bofetada na reserva moral e educacional deste país, privilegiando a alienação e a contra educação, as novelas, os "realitys shows", a ostentação, o "bullying" intelectivo, o ócio improdutivo, enfim, toda a massa intelectivamente improdutiva que vem assolando os lares do país, fazendo às vezes de educadores, ensinando falsos valores e implodindo a educação brasileira.

No país que virou as costas para a Educação e que faz apologia ao hedonismo inconsequente, através de tantos expedientes alienantes, reverencio o verdadeiro herói nacional, que enfrenta todas as intempéries para exercer seu "múnus" com altivez de caráter e senso sacerdotal: o Professor.

\section{III - Dispositivo}

Ante o exposto, JULGO IMPROCEDENTE o pedido inaugural, ao passo em extingo o processo com resolução de mérito, na forma do art. 269, I do Código de Processo Civil.

Sem custas, ex vi do disposto no art. 54 e 55 da lei 9.099/95.

Defiro a gratuidade judiciária ao autor para fins recursais.

Caso haja recurso interposto pelo demandado, proceda a secretaria com a confecção da taxa a recolher, correspondente ao preparo e as custas processuais.

Manejado o recurso no prazo legal, e após o prazo para a apresentação das contrarrazões, com ou sem manifestação da parte adversária, remetam-se os autos 
à Turma Recursal.

Caso não haja recurso, certifique-se o trânsito em julgado e arquive-se os autos com as cautelas de praxe.

Publique-se. Registre-se. Intimem-se as partes.

Após o trânsito em julgado, arquivem-se.

E.S.S.J.

Juiz(a) de Direito

Recebido em 30/03/2016.

Aceito em 05/07/2016. 